\title{
Cultural and practical aspects of halal slaughtering in food production
}

\author{
ABDELBASSET BENZERTIHA, BARTOSZ KIEROŃCZYK*, MATEUSZ RAWSKI*,***, \\ AGATA JÓZEFIAK ${ }^{* *}$, JAN MAZURKIEWICZ ${ }^{* * *}$, DAMIAN JÓZEFIAK*, \\ MOHAMMED SALAH MESSIKH ${ }^{* * * *}$, SYLWESTER ŚWIĄTKIEWICZ***** \\ HiProMine S.A., Poznańska 8, 62-023 Robakowo \\ *Department of Animal Nutrition and Feed Management, Poznań University of Life Sciences, \\ Wołyńska 33, 60-637 Poznań, Poland \\ **Institute of Veterinary Sciences, Poznań University of Life Sciences, Wołyńska 35, 60-637 Poznań, Poland \\ ***Division of Inland Fisheries and Aquaculture, Faculty of Veterinary Medicine and Animal Science, \\ Poznań University of Life Sciences, Wojska Polskiego 71c, 60-625 Poznań, Poland \\ ****Polski Instytut Halal, Gronowa 22/1205, 61-655 Poznań, Poland \\ *****Department of Animal Nutrition and Feed Science, National Research Institute of Animal Production, \\ 32-083 Balice n. Kraków, Poland
}

\section{Benzertiha A., Kierończyk B., Rawski M., Józefiak A., Mazurkiewicz J., Józefiak D., Messikh M. S., Świątkiewicz S. \\ Cultural and practical aspects of halal slaughtering in food production \\ Summary}

The rise in the Muslim population with the economic disability of Muslim countries have made the term halal common all around the world. The lack of information about halal in non-Muslim countries has made the status of imported halal products uncertain for Muslim countries. Halal meat is the most critical product due to the precise rules and requirements needed. In this review, we attempt to explain the types of halal and haram animals as well as the requirements needed for the allowed animals to be halal. Muslims must follow the halal rules mentioned in the Quran, Sunna and doctrines (scholars). The halal animals have been categorized with special and essential slaughtering requirements. However, the slaughtering should be performed in accordance with Islamic rules. The application of animal stunning has been allowed in some Islamic countries since the animal is still alive at the time of slaughtering with respect to animal welfare. Moreover, halal meat loses its halalness as soon as it becomes contaminated with najis (unclean). Indeed, it is important to understand the requirements of halal food, which cover religious aspects.

Keywords: halal, halal animals, animal slaughtering, animal stunning

The term halal has become quite common all around the world. Halal (Arabic: حصلا halāl) is an Arabic word that has various English meanings: permissible, lawful, allowed, authorized, approved, sanctioned, legal, trustworthy, or valid $(14,22,23)$. Its opposite term is haram. For non-Muslim people, the terms halal and haram are associated with food and drink. However, for Muslims, halal is a term that designates any permissible action according to Islamic shari'ah law. The basic Islamic laws are those that were revealed in the Quran by Allah, in Sunnah (the acting of the prophet Mohammed pbh) by the prophet Mohammed (pbh) and in doctrines (Scholars) (23). Accordingly, the lives of Muslims are based on the laws that dictate what is halal and haram. Thus, everything is allowed to be used for Muslims' benefit, except what is forbidden by Islamic shari'ah laws. Those laws are not only applicable to eating and drinking but also to hearing, dress code and dealing with others (humans or animals). In this review, we will mainly focus on food.

Eating and drinking are common points of interest among different religions and ethnicities. Muslims want their food and drink to be halal, Jews want to ensure their food to be Kosher, while Buddhists want their food to be a vegetarian source. Muslims select and designate their food on the basis of the Islamic shari'ah laws. Halal food is the most common interest of Muslims, especially in non-Muslim countries. Moreover, halal rules and requirements are based on religion, not international food safety standards. 
Generally, four major terms other than halal are used to describe the permissibility of food for Muslims:

- haram is directly opposite in meaning to halal. It means prohibited or impermissible;

- mashbooh is a term that means doubtable. This may be due to the absence of direct instruction in the Quran or Sunna and differences in scholars' opinions. According to the opinion of some doctrines, what is mashbooh should be avoided;

- makrooh is a term denoting things detestable by Muslims. Food or acts that are not haram but are disliked by some Muslims. Generally, eating or doing these things are not recommended. However, if they are done, there will be no punishment to the doer;

- najis is a term that means unclean or impure, such as blood, urine, pork meat, and alcohol, among others. Additionally, it can be used when something halal comes in contact with a dirty or haram thing.

Because of the spiritual significance of halal meat to Muslim consumers, the economic benefits associated with trading in such meats and the expansion of the global Muslim population, which is expected to reach 2.76 billion by 2050 (The Pew Research Center, 2015), the halal market continues to increase to cover the needs of the Muslim population. According to the DinarStandard synthesis and analysis report 2015, Brazil is the leading halal meat exporter to OIC countries (Organisation of Islamic Countries) with 15.88 billion USD yearly, followed by India, Argentina, Russia and France (Fig. 1). These five countries rep-
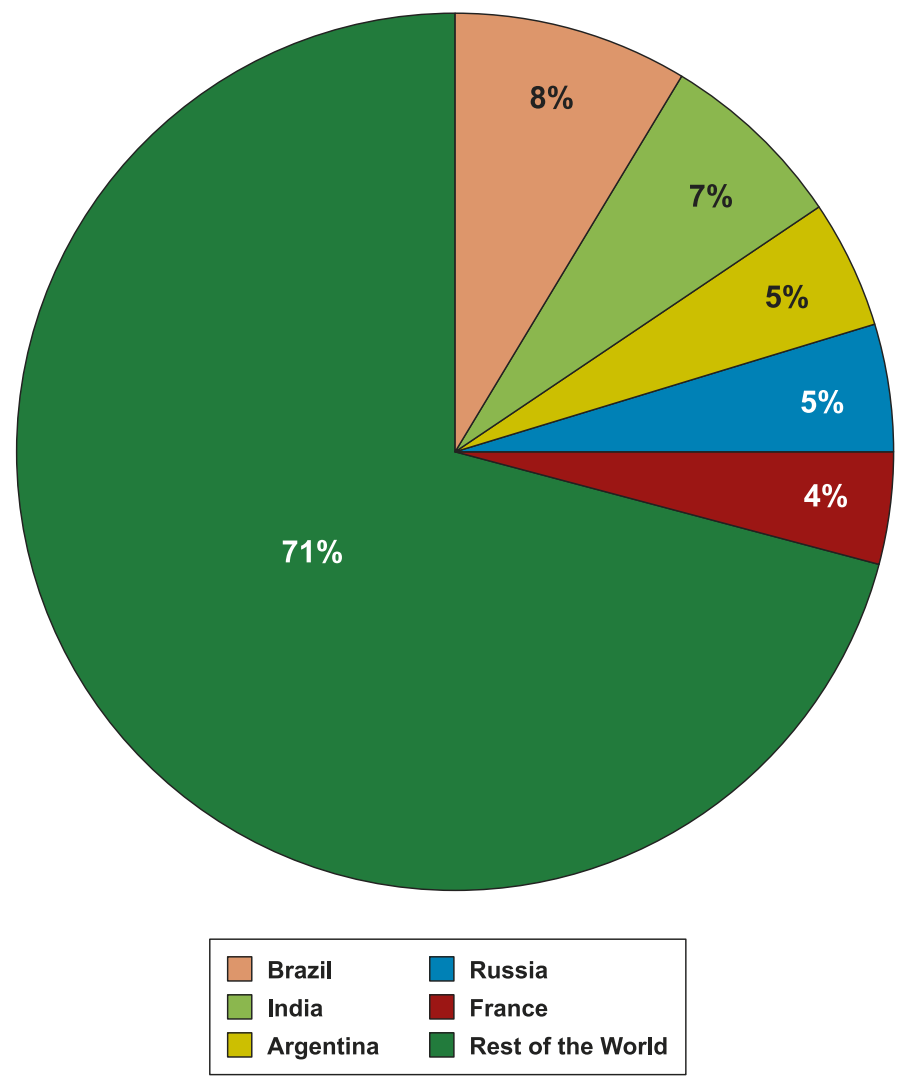

Fig. 1. Top meat exporters to Islamic countries (source: DinarStandard synthesis and analysis report 2015) resent $28.5 \%$ of the total halal meat market. On the other hand, Saudi Arabia is the top importer (21.54 billion USD yearly) followed by Malaysia, UAE, Indonesia and Egypt (Fig. 2). However, the top five halal meat importers represent $42 \%$ of the global halal meat market.

\section{Halal and haram food}

Whatever is mentioned in the Quran and Sunna is the guideline for distinguishing halal from non-halal. The reason for the permission and the interdiction of food is mainly because of beneficial and harmful effects. For Muslims, all foods are halal, except those that are forbidden in the Quran as unclean (najis) and malignant.

In nature, halal foods are divided into four categories:

- halal plants, which is the broadest category of food that covers all types of grain, fruits and vegetables,

- halal animals divided in to two categories, land and aquatic,

- halal drinks, and

- halal solids.

However, within those mentioned categories, there are some exceptions. The latter may lead to the interdiction of use. Generally, the animal category is the most critical one (7). This category is most critical because of the wide species and requirements needed, not only in the animal itself but in the production process as well. In this paper, we will focus on and mainly describe the

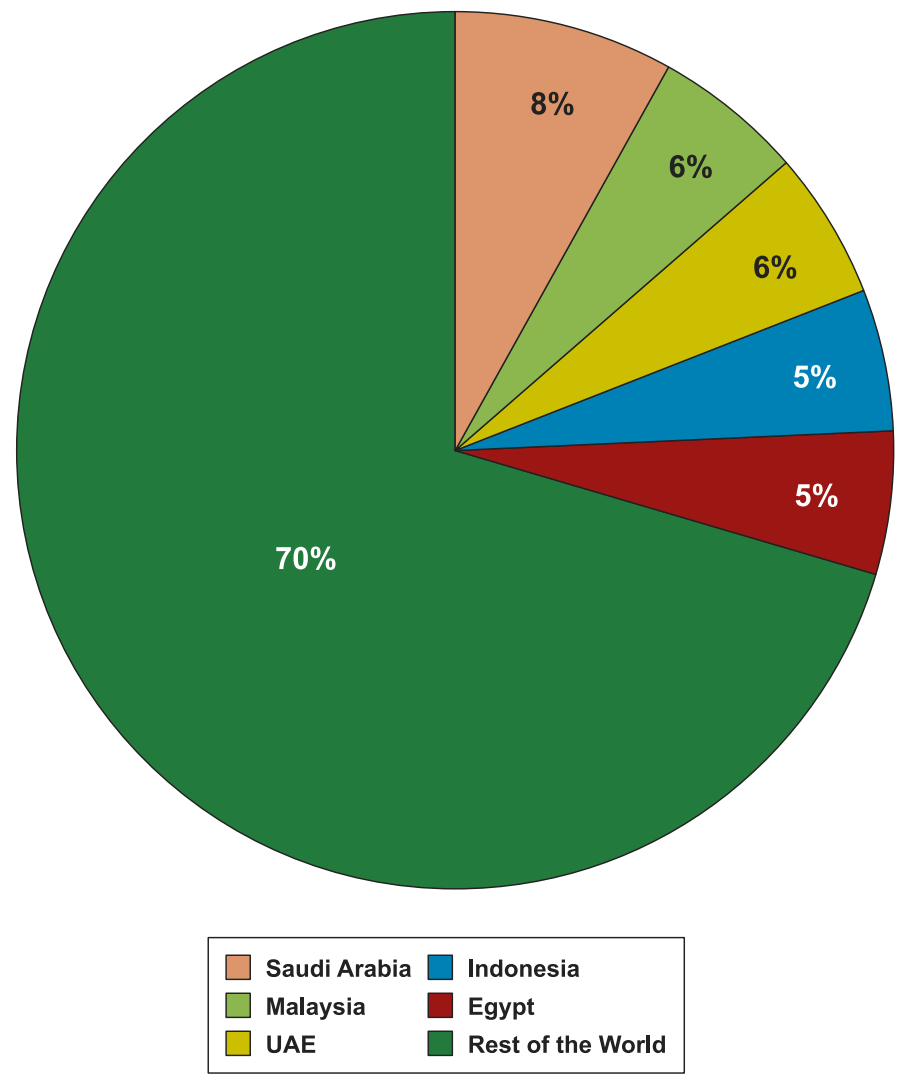

Fig. 2. Top meat importing Islamic countries (source: DinarStandard synthesis and analysis report 2015) 
animal category. Moreover, we will try to explain the types of halal and haram animals and the requirements needed for halal animals.

\section{Halal and haram animals}

According to the Quran, Hadith (the sayings of the prophet Mohammed) and doctrines domesticated ruminants and pseudo-ruminants, non-predatory wild animals, domesticated and non-predatory birds, some insects such as locusts, rabbits and hares (Leporids) are halal. Moreover, all aquatic animals including aquatic crustacea dead or alive are halal. In addition, a fish that dies naturally and is floating on water or lying out of water is still halal as long as it does not show any signs of decay or deterioration (Tab. 1). Spiny-tailed lizards, hyenas and horses are halal, but they are detestable by some Muslims (makrooh).

Haram animals are mainly mentioned in the following verses of the Quran:

"Forbidden unto you (for food) are carrion and blood and swine flesh, and that which hath been dedicated unto any other than Allah, and the strangled, and the dead through beating, and the dead through falling from a height, and that which hath been killed by (the goring of) horns, and the devoured of wild beasts saving that which ye make lawful (by the death-stroke) and that which hath been immolated unto idols. And (forbidden is it) that ye swear by the divining arrows. This is an abomination...". Chapter V, Verse 3.

According to the above verses, all kinds animals are halal except those mentioned. However, any kind of products coming from the following are not halal:

- carrion or dead animals,

- in the Quranic verse, blood from permitted and prohibited animals is haram. Anything made or sourced from blood is haram; this fact is also agreed on by all Islamic scholars,

- swine,

- animals slaughtered without pronouncing the name of Allah on them, and

- animals slaughtered while pronouncing a name other than Allah.

Whereas there is a clear identification of haram animals in Islam (Tab. 1) that were mentioned to be haram by the prophet Mohammed (pbh) and doctrines:
- any animal that has long pointed teeth or tusks, all primates, all reptiles except spiny-tailed lizards, donkeys and mules are haram. However, eating of horse was not forbidden by the prophet Mohammed (pbh). Most insects. However, there is no clear established status about insects in Islam,

- all predatory birds with sharp claws; whilst, crow and parrot are doubtful birds (20),

- any animal that comes from an eatable and noneatable parent is non-halal such as mule, which comes from horse and donkey, and lycaon pictus, which comes from hyena and wolf,

- animals that are not allowed to be killed in Islam such as honeybees and hoopoe,

- all aquatic animals that are harmful to human health are haram,

- all amphibious animals are haram.

\section{Islamic rules and requirements in halal animals}

Almost every Muslim practicing or not practicing Islam pays close attention to what he/she eats $(6,7)$.
Tab. 1. Halal and haram animals in the Islamic point of view

\begin{tabular}{|c|c|c|}
\hline \multirow{2}{*}{ Animals } & \multicolumn{2}{|c|}{ Islamic opinion } \\
\hline & Halal & Haram \\
\hline \multicolumn{3}{|c|}{ Vertebrates } \\
\hline Mammals & $\begin{array}{l}\text { Domesticated and wild Ruminants: cow, } \\
\text { goat, sheep, buffalo, roe deer, moose, } \\
\text { reindeer, chamois, red deer, fallow, } \\
\text { wisent, aurochs } \\
\text { Pseudo-ruminants: camel } \\
\text { Monogastrics: horse, zebra } \\
\text { Carnivores: hyena } \\
\text { Lagomorphs: rabbit, hare } \\
\text { Cetaceans: whale and dolphin }\end{array}$ & $\begin{array}{l}\text { Primates: monkey, gorilla, chimpanzee } \\
\text { Monogastrics: donkey, mule and swine } \\
\text { Carnivores: dog, cat, wolf, fox, lion, bear, } \\
\text { tiger, jackal, raccoon, river otter, short } \\
\text { tailed weasel, cheetah, leopard, panther, } \\
\text { squirrel, marten } \\
\text { Rodents: mouse, hamster, gerbil, } \\
\text { chipmunk, gray squirrel, flying squirrel, } \\
\text { prairie dog, beaver, capybara, porcupine } \\
\text { Flying mammals: bats, black flying fox } \\
\text { Seals: walrus, gray seal, leopard seal }\end{array}$ \\
\hline Birds & $\begin{array}{l}\text { Game birds and fowl: partridge, } \\
\text { quail, pheasant, guinea fowl, grouse, } \\
\text { megapode, chukar, ptarmigan, monal, } \\
\text { capercaillie, chickens, geese, ducks, } \\
\text { turkey, mallard, graylag } \\
\text { Doves and pigeons } \\
\text { Ratite: ostrich, emu, kiwi, rhea }\end{array}$ & $\begin{array}{l}\text { Avian raptors: falcon, eagle, osprey, kite, } \\
\text { accipiter, buteo hawk, harriers, secretary } \\
\text { bird, turkey vulture, buzzard, condor, } \\
\text { gyrfalcon, merlin, lammergeier, kestrel, } \\
\text { caracara, bateleur, goshawk } \\
\text { Owls } \\
\text { Hoopoe (not allowed to be killed in Islam) }\end{array}$ \\
\hline Fish & All fish & - \\
\hline Reptiles & Spiny-tailed lizard & All reptiles \\
\hline Amphibians & - & All amphibians \\
\hline \multicolumn{3}{|c|}{ Invertebrates } \\
\hline Annelid & Marine and fresh water species & Terrestrial species \\
\hline Mollusks & $\begin{array}{l}\text { Marine and fresh water species: sea } \\
\text { slug, squid, octopus, nautiluse, mussel, } \\
\text { scallop, clam } \\
\text { Terrestrial species: snail }\end{array}$ & Terrestrial species \\
\hline \multicolumn{3}{|c|}{ Arthropods } \\
\hline Chelicerate & Horseshoe crab & Arachnids: scorpion, spider \\
\hline Myriapods & - & Millipedes, centipede \\
\hline Crustacea & $\begin{array}{l}\text { Marine and fresh water crustacea, crabs, } \\
\text { lobster, crayfish, shrimp, krill, woodlice } \\
\text { and barnacle }\end{array}$ & $\begin{array}{l}\text { Terrestrial crustacea: terrestrial crab, } \\
\text { terrestrial hermit crab, woodlice }\end{array}$ \\
\hline Hexapod & Winged insect: locust & $\begin{array}{l}\text { Winged and non-winged insects, bee (not } \\
\text { allowed to be killed in Islam) }\end{array}$ \\
\hline
\end{tabular}


Islam in the Quran and hadith in general emphasizes the rules for halal food and halal meat in particular. Some of those principals are clearly described in the Quran and hadith, and some of them are taken and released by Muslim jurists. Approximately $90 \%$ of Muslims are Sunni, and 10\% are other denominations (21). However, this review will follow the Sunni practices. The basic principal is that the things created by Allah are permitted with some exceptions for those prohibited once. What is halal is permitted and what is haram is prohibited, and a few items between them come into doubt. Those things prohibited by Allah are unquestionable. Prophet Muhammad (pbh) said: "The halal is clear, and the haram is clear. Between the two, there are doubtful matters concerning which people do not know whether they are halal or haram. One who avoids them in order to safeguard his religion and his honour is safe, while if someone engages in a part of them, he may be doing something haram...".

As mentioned before, Chapter V, Verse 3 in the Quran describes what is prohibited for Muslims to eat: carrion or dead animals, blood, and swine as well as animals slaughtered without pronouncing the name of Allah or while pronouncing a name other than Allah. Animals that die of natural causes such as diseases, being gored by other animals, being strangled, falling from a height, being beaten, or killed by wild beasts are prohibited to eat unless they are saved by slaughtering before they actually die. However, some principals and rules are required to be implemented on the permitted animals such as slaughtering and processing.

\section{Animal feed perspective}

The life of an animal, from its birth until its ritual slaughter, is under control of religious strategies. There has been controversy about animal feed composition and the application of animal by-products and their extracts into animal diet, including those from swine. Some scholars believe that feeding an animal with feed that contains any part of a haram animal is unclean and prohibited from being slaughtered. Some other scholars believe that an animal that lives in filth and eats filth all the time is categorized as unclean and is prohibited. "Al-jalalah" is a term used to describe animals that consistently or rarely eat the waste of other animals, carrion, or pigs and its derivatives and a change in their appearance, odor, or taste (24). Prophet Mohammed forbade eating the meat and milk from such animals (14). However, the term "Al-jalalah" will not be practiced on those animals that eat from filth and clean feed. Most Muslims believe that the feed for an animal, whether this animal is raised for meat, milk or eggs, must be a plant origin diet. Some other Muslims believe that only pork and non-halal animal by-products are forbidden from animal nutrition (23). For this Saudi Arabia has banned the use and exportation of animals fed a diet that contains by-products of prohibited animals $(14,24)$.

\section{Slaughtering of halal animals}

The term "dhabh" is used when animals are permitted and required to be slaughtered. This is for the sole purpose of making it fit for consumption. The word "dhabh" is an Arabic term that means "to slaughter." Islamic law has enacted some rules and conditions on the act of slaughtering and on the animal to be slaughtered. Those rules must be followed to the end with a pure halal product until the last consumer. Followers of Islam are careful about eating what is halal-un-Tayiban which means, "allowed, permitted and wholesome" - "O mankind! Eat of that which is lawful and wholesome on earth..." [Quran II:168]. The principals of proper slaughtering and bleeding are applicable to land animals and birds but not to fish and other creatures that live in water. Similarly, there is no specially mentioned method of killing locust. However, the slaughter of animals in accordance with Islamic law shall meet the following requirements:

- the animal must be a permitted species for Muslims and required slaughtering;

- the animal must be alive and healthy at the time of slaughtering;

- the slaughter-man must be adult and sane (mentally competent) and possess an intractable faith and knowledge of basic animal slaughter and welfare. The slaughter-man can be a Muslim or from the people of the book (Christians and Jews) as it is mentioned in the Quran, Chapter V Verse 5 "This day, all good things are made lawful for you. The food of those who have received the Scripture is lawful for you, and your food is lawful for them." However, a Jewish or Christian slaughter-man must meet all halal requirements described herein;

- the slaughter-man must pronounce aloud and in full dignity the following Arabic words: „Bismillah, Allahu Akbar”, which means, „In the name of Allah, Allah is the greatest." "And eat not of that whereupon Allah's name hath not been mentioned, for lo! It is an abomination." [Quran VI:121] The slaughter-man should not mention any other name than Allah and it must be mentioned for each animal separately;

- the slaughter should be done by a throat cut, which helps induce rapid and complete bleeding. The cutting of the trachea, esophagus, carotid arteries and jugular veins is required. However, in most scholars, cutting three out of four is acceptable. Dorsal cuts, decapitation, "sawing", and any severing of the spinal cord disqualify the halal sacrifice $(8,21)$;

- the slaughter act shall be done once, which is difficult to achieve in large animals (11), by a sharp knife free from scratches and nicks (1), with a suitable length to perform the slaughtering properly and preferably four times the size of the neck of the animal. According to Grandin and Regenstein (12) a straight sharp knife that is twice the size of the neck can reduce the pain. No special knives are dedicated to halal 
animal slaughtering. A study conducted by Velarde et al. (25) reported that the length of the knives dedicated to halal ritual slaughtering in different abattoirs varies between $29 \pm 1.79 \mathrm{~cm}$ for cattle, $22.2 \pm 1.82$ for sheep and $13 \mathrm{~cm}$ for poultry. In Islam, each knife meeting the above mentioned requirements is acceptable, except for bones, claws, teeth, nails, and the like. In a hadith, the Prophet (pbh) states that: "Use everything to slaughter which allows blood to flow, with the exception of teeth and nails, all else is permissible";

- the ritual slaughter must be conducted with a strict protocol of cleanliness. Moreover, the terrain where the sacrifice is to be done shall be free from any kind of haram animals.

Islam has emphasized gentle and humane treatment of animals before and during slaughtering. The animal must be treated humanely with no source of stress to reduce the animal's suffering. "Allah, Who is blessed and exalted, has prescribed benevolence towards everything; so, when you must kill a living being, do it in the best manner, and when you slaughter an animal, you should sharpen your knife so as to cause the animal as little pain as possible." Some other conditions should be taken into consideration before slaughtering the animal. These conditions include giving some rest and water to the animal, not sharpening the knife in front of the animal and avoiding slaughtering in front of other animals (17). The prophet Mohammed said when he saw a man sharpening his knife in front of an animal: "do you wish to slaughter this animal twice, once by sharpening your blade in front of it and another by cutting its throat?". After the slaughtering, there must be enough time for bleeding, and the dismemberment can start when the animal is completely lifeless.

Hunting is also allowed in Islam only for the purpose of eating. The hunting of permitted wild animals, birds or uncontrolled animals can be done by any tool such as a gun, arrows, spears, or traps. Additionally, a trained dog may be used for catching or retrieving the prey. The name of Allah shall be pronounced during the release of the tool. Moreover, the hunted animal should be slaughtered as soon as it is caught. However, if the animal dies from the hunting tool, it is still halal. Big animals such as camels can be slaughtered in a different way by cutting the throat (the aorta) with a slashing movement of the knife along the animal's neck up to the top of its chest.

\section{Animal stunning and halal perspective}

One of the most important rules during halal slaughtering is that the animal must be alive at the time of the slaughter. Moreover, some Muslims insist that the animal must be conscious at the time of slaughtering. Animal stunning aims to ensure that the animal does not feel any pain during the act of slaughtering (4, $10,15,19)$. This has attracted much interest from the animal welfare perspective (2). Effective stunning ensures that the animal is unconscious. However, animal stunning was not used during the reign of the prophet Mohammed (pbh). There is a possibility that some animals may die after being stunned (11). Moreover, the unconsciousness may prevent the slaughter-man from confirming the halal status of the animal, as the animal must be alive. Some scholars have accepted some kind of stunning so long as the stunned animal is still alive before the cut (11). Because of these surrounding uncertainties about the life of the animal after stunning, the Muslim prefers their meat slaughtered without any kind of stunning (18). There are different stunning techniques that include electrical, mechanical and gas or low atmosphere stunning with different applications $(13,16,26)$, and they may influence the animal's welfare and the meat quality (2). The acceptance of stunning in halal animal slaughtering has been the subject of controversy between certification bodies (HCBs) and countries (5). Some countries (such as Malaysia, Indonesia) accept pre-slaughter stunning using a water bath stunner for poultry, and head only electrical stunning and non-penetrating pneumatic stunner for ruminants (17). On the other hand, Gulf countries do not accept stunning for poultry (GSO 993:2015). In the EU countries, halal meat is produced from both stunned and non-stunned animals, according to the EU legislation on the protection of animals at the time of killing ("Council Regulation (EC) No 1099/2009"). However, there is mandatory animal pre-stunning with an exception for religious needs. The most applicable stunning for halal production is electrical with a specific current and frequency (Tab. 2). Moreover, the below mentioned current for each species must be amended in accordance with the weight of the animal. A study on poultry stunning done by Anil (2) showed that only $50 \mathrm{~Hz}$ frequency with a sinusoidal waveform applied on the chest would kill by stopping the heart while a frequency over $100 \mathrm{~Hz}$ would not kill. Generally, the applicable stunning technique must neither kill nor cause any further injury to the animal $(17,23)$.

Muslims consider the consumption of halal products as one of the acts of worship, as it is a commandment

Tab. 2. Parameters for electrical stunning (5)
\begin{tabular}{|l|c|c|}
\hline \multicolumn{1}{|c|}{ Type of animal } & Current (Ampere) & Duration (Seconds) \\
\hline Chicken & $0.25-0.50$ & $3.00-5.00$ \\
\hline Lamb & $0.50-0.90$ & $2.00-3.00$ \\
\hline Goat & $0.70-1.00$ & $2.00-3.00$ \\
\hline Sheep & $0.70-1.20$ & $2.00-3.00$ \\
\hline Calf & $0.50-1.50$ & 3.00 \\
\hline Steer & $1.50-2.50$ & $2.00-3.00$ \\
\hline Cow & $2.00-3.00$ & $2.50-3.50$ \\
Bull & $2.50-3.50$ & $3.00-4.00$ \\
\hline Buffalo & $2.50-3.50$ & $3.00-4.00$ \\
Ostrich & 0.75 & 10.00 \\
\hline
\end{tabular}


from Allah. The rules on halal production are detailed in the Quran, Sunna and doctrines. However, the most important rules are those on animal slaughtering. It is obligatory to follow the requirements on the slaughter of animals in Islam. The animal must be alive at the time of slaughter, the slaughter shall be done by a Muslim or by one from the people of the book. The slaughter-man must be rational, mature and familiar with the rules and conditions related to Islamic shari' ah slaughter requirements. A sharp knife must be used for this purpose. Moreover, the slaughter-man must pronounce the name of Allah and cut the front of the neck severing carotid arteries, jugular veins, trachea, and esophagus without cutting the spinal cord. The bleeding shall be complete, and the dismemberment can start when the animal is completely lifeless. Some kinds of stunning are allowed as long as the animal stays alive at the time of slaughtering and it does not cause any permanent physical injury to the animal.

\section{References}

1. Aghwan Z. A., Bello A. U., Abubakar A. A., Imlan J. C., Sazili A. Q.: Efficient halal bleeding, animal handling, and welfare: A holistic approach for meat quality. Meat Sci. 2016, 121, 420-428.

2. Anil M. H.: Effects of slaughter method on carcass and meat characteristics in the meat of cattle and sheep. EBLEX - a Division of the Agriculture and Horticulture Development Board, Warwickshire, UK 2012.

3. Anil M. H., Raj A. B. M., McKinstry J. L.: Electrical stunning in commercial rabbits: Effective currents, spontaneous physical activity and reflex behaviour. Meat Sci. 1998, 48, 21-28.

4. Anil M. H., Raj A. B. M., McKinstry J. L.: Evaluation of electrical stunning in commercial rabbits: effect on brain function. Meat Sci. 2000, 54, 217-220.

5. Anil M. H., Yesilderet T., Aksut H., Maturt E., McKinstryt J. L., Weavert H., Mason $C$.: Comparison of halal slaughter with captive bolt stunning and neck cutting in cattle: Exsanguination and quality parameters. Anim. Welfare 2006, $15,325-330$.

6. Bergeaud-Blackler F.: De la viande halal à l'halal food. Comment le halal s'est développé en France? Revue Europ. Migrations Internat. 2005, 21, 125-147.

7. Bonne K., Verbeke $W$.: Religious values informing halal meat production and the control and delivery of halal credence quality. Agric. Human Values 2008, 25, 35-47.

8. Ceranić S., Bozinović N.: Possibilities and significance of HAS implementation (halal assurance system) in existing quality system in food industry. J. Biotechnol. Anim. Husbandry 2009, 25, 261-266.
9. Chaudry M. M., Regenstein J. M.: Implications of biotechnology and genetic engineering for kosher and halal foods. Trends Food Sci. Tech. 1994, 5, 165 -168 .

10. Craig E., Fletcher D.: A comparison of high current and low voltage electrical stunning systems on broiler breast rigor development and meat quality. Poultry Sci. 1997, 76, 1178-1181.

11. Fuseini A., Knowles T. G., Hadley P. J., Wotton S. B.: Halal stunning and slaughter: Criteria for the assessment of dead animals. Meat Sci. 2016, 119, 132-137.

12. Grandin T., Regenstein J.: Religious slaughter and animal welfare: A discussion for meat scientists. Meat Focus Int. 1994, 3, 115-123.

13. Gregory N. G.: Recent concerns about stunning and slaughter. Meat Sci. 2005 70, 481-491.

14. Khattak J. Z. K., Mir A., Anwar Z., Abbas G., Khattak H. Z. K., Ismatullah H.: Concept of halal food and biotechnology. Adv. J. Food Sci. Technol. 2011, 3, 385-389.

15. Limon G., Guitian J., Gregory N. G.: An evaluation of the humaneness of puntilla in cattle. Meat Sci. 2010, 84, 352-355.

16. McNeal W. D.: Influence of high frequency electrical stunning and decapitation on broiler activity during slaughter on carcass and meat quality. (MSc Dissertation). University of Georgia 2002.

17. Nakyinsige K., Fatimah A. B., Aghwan Z. A., Zulkifli I., Goh Y. M., Sazili A. Q.: Bleeding efficiency and meat oxidative stability and microbiological quality of New Zealand White rabbits subjected to halal slaughter without stunning and gas stun-killing. Asian Austral. J. Anim. 2014, 27, 406-413.

18. Nakyinsige K., Man Y. C., Aghwan Z. A., Zulkifli I., Goh Y. M., Bakar F. A., Sazili A. $Q$.: Stunning and animal welfare from Islamic and scientific perspectives. Meat Sci. 2013, 95, 352-361.

19. Öneç A., Kaya A.: The effects of electrical stunning and percussive captive bolt stunning on meat quality of cattle processed by Turkish slaughter procedures. Meat Sci. 2004, 66, 809-815.

20. Qureshi S. S., Jamal M., Qureshi M. S., Rauf M., Syed B. H., Zulfiqar M., Chand $N$.: A review of Halal food with special reference to meat and its trade potential. J. Anim. Plant Sci. 2012, 22, 79-83

21. Regenstein J. M., Chaudry M. M., Regenstein C. E.: The kosher and halal food laws. Compr. Rev. Food Sci. F. 2003, 2, 111-127.

22. Riaz M. N.: Hailing halal. Prepared Foods 1996, 165, 53-54.

23. Riaz M. N., Chaudry M. M.: Halal food production. CRC Press, Florida, Boca Raton 2003.

24. Saidin N., Rahman F. A.: Halal feed for halal food: An exploratory study of the Malaysian legal and regulatory framework on animal feed, [in:] Manan S. K. A., Rahman F. A., Sahri M. (ed.): Contemporary issues and development in the global halal industry. Springer, Singapore 2016, 141-151.

25. Velarde A., Rodriguez P., Dalmau A., Fuentes C., Llonch P., Holleben K. V., Cenci-Goga B. T.: Religious slaughter: Evaluation of current practices in selected countries. Meat Sci. 2014, 96, 278-287.

26. Zivotofsky A. Z., Strous R. D.: A perspective on electrical stunning of animals: Are there lessons to be learned from human-electro convulsive therapy (ECT)? Meat Sci. 2012, 90, 956-961.

Corresponding author: MSc Abdelbasset Benzertiha DVM, ul. Poznańska 8 , 62-023 Robakowo; e-mail: abdelbasset.benzertiha@hipromine.com 